\title{
Acute Appendicitis Presenting with Small Intestinal Obstruction Findings 2 Cases Report
}

\author{
Ince Barsak Obstrüksiyonu Bulguları ile Başvuran \\ Akut Apandisit - 2 Olgu Sunumu \\ Fatih Altıntoprak', Enis Dikicier², Güner Çakmak², Ömer Yalkın², \\ Gökhan Akbulut', Osman Nuri Dilek' \\ ${ }^{1}$ Sakarya University Faculty of Medicine, Department of General Surgery \\ ${ }^{2}$ Sakarya University Research and Educational Hospital, Department of General Surgery
}

Yazışma Adresi / Corresponding to:

Yrd. Doç. Dr. Fatih Altıntoprak, Korukent Sitesi Korukent Bloklar Mimoza-3 D: 10 Korucuk I Adapazarı 54000 Sakarya - Türkiye Gsm: 05335483415 e-mail : fatihaltintoprak@yahoo.com

Akut apandisit ve ince barsak obstrüksiyonları acil servislerde sık karşılaşılan cerrahi problemlerdir. Akut apandisit nadiren ince barsak obstrüksiyonu bulguları ile prezente olabilir. 68 yașında kadın ve 42 yașında erkek hastalar intestinal obstrüksiyon bulguları nedeniyle acil serviste değerlendirildi. Hastaların birinde obstrüksiyon nedeni perfore apandisit nedenli paralitik iken, diğerinde uzun apendiksin terminal ileuma basısı nedeniyle mekanikti. Her iki hastaya da apendektomi uygulandı ve ameliyat sonrası dönemleri sorunsuz seyretti. Akut apandisit en sık karşış̧ılan akut karın sendromu etyolojisi olmasına rağmen nadiren beklenmedik klinik bulgularla prezente olabilir.

Anahtar Kelimeler: Intestinal obstrüksiyon, Akut apandisit; Perfore apandisit

Acute appendicitis and small intestinal obstructions are frequent surgical problems encountered by emergency departments. Acute appendicitis rarely presents as a finding of small intestinal obstruction. A sixty-eight-year-old woman and a forty-two-year-old man consulted the emergency department with findings of intestinal obstruction. The reasons for intestinal obstructions were paralytic in one patient, due to perforated appendix; in the other, mechanic, due to the obstruction of the terminal ileum by a long appendix. Both cases underwent appendectomies, and their post-operational periods were uncomplicated. As the most frequent surgical acute abdominal syndrome etiology, appendicitis may appear with unexpected clinical manifestations.

Keywords: Intestinal obstruction, Acute appendicitis; Perforated appendicitis 


\section{Giriş}

Acute appendicitis is the most common emergency surgical condition in worldwide. Clinical findings of acute appendicitis that are accepted as 'typical' are only seen in $60 \%$ of all patients. In other patients, various non-typical clinical findings are encountered. Small intestinal obstructions are another surgical situation frequently encountered by emergency departments. Intestinal obstructions are generally seen in their mechanical form, and their etiology is most commonly postoperative adhesions. ${ }^{1}$

Acute appendicitis rarely presents in small intestinal obstruction findings. The reason for intestinal obstruction in acute appendicitis is generally adhesions due to periappendicular inflammation or localized/generalized peritonitis due to a perforated appendix. ${ }^{2}$ However, since the appendix is a mobile organ, its location may change inside the abdomen, and in cases of inflammation it may adhere to surrounding tissues causing a subsequent mechanical obstruction, as seen in one of the cases in this report. ${ }^{3}$ In this article 2 appendicitis cases with intestinal obstruction are reported.

\section{Case 1:}

A sixty-eight-year-old woman with abdominal pain and vomiting complaints consulted the emergency unit on the fourth day of her complaints. No abdominal operation were present in her medical history. Abdominal distension and diffuse tenderness were present in her physical examination, and intestinal sounds were increasing. Leukocytosis was present according to whole blood count, which was $12 \times 10^{3} / \mathrm{mm}^{3}$. Intestinal-type air-fluid levels were detected by abdominal graphy, and subsequently a computed tomography (CT) scan was performed. According to $\mathrm{CT}$, dilatation was present in all segments of the small intestine, and inflammation was present in the pericecal area (Figure 1a). In operation, perforated appendicitis and a paralytic obstruction secondary to the inflammation in the terminal ileum were determined (Figure 1b). Appendectomy was performed following abscess drainage, and the patient was discharged on the third day postoperation without complications.

\section{Case 2.}

A forty-two-year-old man with abdominal pain and vomiting complaints consulted the emergency unit on the second day of his complaints. Abdominal distension, diffuse tenderness and defance were present in his physical examination, and intestinal sounds were increasing. Small intestinal-type air-fluid levels were detected by direct abdominal graphy. Leukocytosis was present according to the whole blood count, which was $18 \times 10^{3} / \mathrm{mm}^{3}$. The patient had no medical history of abdominal initiations, and a CT scan with oral contrast material was performed. According to the $\mathrm{CT}$ a sudden narrowing was present in the small intestinal lumen of the terminal ileum, and the intestinal segments proximal to this point were dilated (Figure 2a). With a primary diagnosis of acute mechanical obstruction, the patient underwent emergency surgery. During surgical exploration, a long appendix and acute appendicitis were discovered; after leaving the cecum, the appendix wrapped around the ileum loop and mesenterium like a napkin ring, and adhered to the cecum once more. It was determined that the reason for intestinal obstruction was the mechanical pressure exerted by the appendix on the ileal loop (Figure $2 \mathrm{~b}$ and $\mathrm{c}$ ). The operation was terminated following appendectomy. The patient was discharged on the third day post-operation without complications.

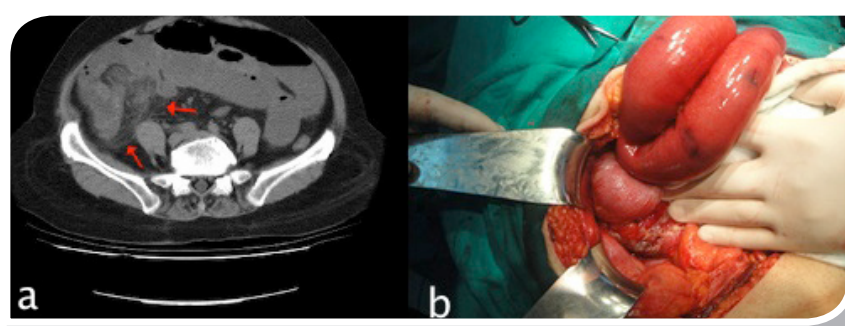

Figure 1: Abdominal $\mathrm{CT}$; a) dilatation was present in all segments of the small intestine, and inflammation was present in the pericecal area (arrows). This appearance suggest that a perforated appendicitis. Intraoperative appearance; b) perforated appendicitis and intense inflammation seen.

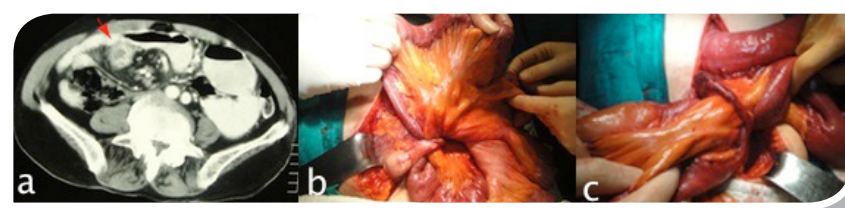

Figure 2: (a) Abdomen $\mathrm{CT}$; a) It's the dilatation in proximal intestine segments and partial stricture on ileum level seen (arrow). No inflamation symptom or free fluid in the abdomen. Intraoperative appearance; b-c) It's the adhesion of long appendix to intestine mesentery depending on inflamation and its ileum segment comp- 


\section{Discussion:}

Acute appendicitis is the most frequent acute abdominal syndrome etiology of abdominal surgeries. The probability of a person developing acute appendicitis during their lifetime has been calculated as 7\%. A careful medical history and a detailed physical examination are the basic tools in the diagnosis of acute appendicitis. The presence of leukocytosis in laboratory test results is a supportive finding in the diagnosis. Despite these diagnostic tools, radiological monitoring is needed for diagnosis in approximately one third of all patients. On the other hand, intestinal obstructions form $20 \%$ of all emergency surgical operations and $60 \%$ of these involve the small intestine.4 Post-operative adhesions are the most frequent cause of small intestine obstructions in adults, and are the first etiologic diagnosis considered in patients with intestinal obstructions and abdominal surgery history. Clinical findings of intestinal obstruction and leukocytosis were present in both the cases presented in our report upon initial consultation, but neither had a history of abdominal surgery.

The presentation of acute appendicitis via intestinal obstruction findings is a rare situation and what is extremely rare is its appearance via a mechanical obstruction. ${ }^{3}$ The mechanism involved in these cases was first defined in 1901 and in 1908 it was classified into 3 sub groups: mechanical, septic, and combined types. 5 Early and correct diagnosis of patients with mechanical small intestine obstruction is important for reducing morbidity and mortality. If the etiologic factor is acute appendicitis with suppressed clinical manifestations in a patient with delayed diagnosis of mechanical small intestine obstruction, the morbidity and mortality risk will no doubt increase by the hour. It is predicted that results will develop progressively, particularly in patients of advanced age; clinical manifestations occur more often in this age group. The importance of early diagnosis and definitive therapy may be better understood in light of one of our patients, who was in the $>65$ age group and had no clinical or radiological findings suggesting acute appendicitis.

Acute appendicitis-dependent small intestine obstructions may be placed in 2 main categories, paralytic and mechanic, if the combined type comprising both situations together is put aside. Paralytic is the most common etiology, and the physiopathology may be defined as the reduction of peristalsis in the adjacent small intestinal segment caused by peri-appendicular inflammation. ${ }^{2}$ The physiopathology of mechanical causes is the mechanical pressure on the adjacent small intestinal segment. ${ }^{6}$ The etiology of the obstruction in our first patient was paralytic, whereas in our second patient it was mechanical, which is a very rare, as we mentioned above.

Although detailed anamnesis, physical examination, laboratory tests, and conventional graphies aid in the diagnosis of obstruction in patients with obstructional findings, CT is a more sensitive method of diagnosis. The degree (completepartial), the level (small intestine-colon), and the etiology (intra-luminal/extra-luminal) of the obstruction and the presence of other accompanying intra-abdominal pathologies may be determined by CT. Balthazar et al. ${ }^{7}$ reported that the sensitivity, specificity, and accuracy of abdominal CT in the diagnosis of mechanical small intestine obstructions are 83\%, 93\%, and $91 \%$ respectively, and they remarked on the superiority of $\mathrm{CT}$, especially in patients with small intestine obstructional findings with no clarified etiology despite clinical-biochemical or radiological examinations. Intestinal obstructional findings, leukocytosis, and intestinal-type air-fluid levels were present in both of our patients upon consultation, but abdominal CT scanning was needed since these findings did not suggest a specific diagnosis. The etiological cause in the first patient was perforated appendicitis, and it was discovered in the preoperative period via CT. In the second patient only obstruction of the terminal ileum level was determined via $\mathrm{CT}$; the real diagnosis was determined during the operation.

In conclusion, as the most frequent surgical acute abdominal syndrome etiology, appendicitis may appear with unexpected clinical manifestations depending upon appendix length, location inside the abdomen, and degree of inflammation, in addition to its known classical findings.

\section{Conflict of Interest :}

The authors declare that have no conflict interest 


\section{References}

1. Macari M, Megibow A. Imaging of suspected acute small bowel obstruction. Semin Roentgenol 2001; 36(2):108-17.

2. Gupta S, Vaidya M. Mechanical small bowel obstruction cased by acute appendicitis. Am Surg 1969; 35(9):670-4.

3. Assenza M, Ricci G, Bartolucci P, Modini C. Mechanical small bowel obstruction due to an inflamed appendix wrapping around the last loop of ileum. G Chir 2005; 26(6-7): 261-6.

4. Peck JJ, Milleson T, Phelan J. The role of computed tomography with contrast and small bowel follow-through in management of small bowel obstruction. Am J Surg 1999; 177(5):375-8.

5. Hawkes F. III. The prevention of intestinal obstruction following operation for appendicitis. Ann Surg 1909; 49(2):192-207.

6. Deshmukh SN, Maske AN, Bote SM, Parashi HS. Small bowel obstruction caused by appendiceal tourniquet. Am J Surg 2011; 201(2):e21-2.

7. Balthazar EJ, Liebeskind ME, Macari M. Intestinal ischemia in patients whom small bowel obstruction is suspected: evaluation of accuracy, limitations, and clinical implications of CT in diagnosis. Radiology 1997; 205(2):519-22. 